\title{
MOLECULAR EPIDEMIOLOGY OF HEPATITIS C VIRUS (HCV) IN KADUN STATE.
}

\author{
Sheyin, $\mathrm{Z}^{1^{*}}$, Jatau, E $\mathrm{D}^{2}$., Mamman, A. I ${ }^{3}$., Randawa, A J*.
}

1. Hajiya Gambo Sawaba General Hospital Zaria, Kaduna State Ministry of Health. 2. Department of Microbiology, Ahmadu Bello University, Zaria, 3. Department of Haematology Ahmadu Bello University Teaching Hospital, Zaria, 4. Department of Obstetric \& Gynaecology, Ahmadu Bello University Teaching Hospital, Zaria.

*Correspondence: Phone number 08023792784 E-mail sheyinzakka@yahoo.com

\section{ABSTRACT}

Objective: To determine the distribution of hepatitis $\mathrm{C}$ virus (HCV) genotypes and subtypes among blood donors and outpatients attendees positive for antibody to $\mathrm{HCV}$ (anti-HCV).

Justification: Hepatitis C virus (HCV) continues to be a major disease burden on the world and Man is the only known natural host of Hepatitis C virus (Chivaliez and Pawlotsky, 2007). . There is no published data on the prevalence of the genotypes and subtypes of HCV in Kaduna State.

Setting: Three hospitals one in each of the 3 senatorial zones in Kaduna State.

Patients: Blood donors who reported for blood donation and outpatient department attendees.

Method: Antibody detection by a third generation HCV ELISA (Biotech Laboratories, UK); HCV RNA and genotyping by Reverse Transcriptase polymerase chain reaction with genotype-specific primers. (Sacace Biotechnologies, UK).

Results: of the 259 plasma specimens screened for Hepatitis C virus in this study, 20(7.7\%) were positive for anti-HCV antibodies by ELISA and 16(6.2\%) of the antibodies positive specimen were positive for HCV RNA. Of the 139 blood donors tested, 8 (5.8\%) were HCV RNA positive. Similarly, 120 were tested from the outpatient Department attendees and $8(6.7 \%)$ were HCV RNA positive. Hepatitis $C$ virus genotype $1 \mathrm{~b}$ was found in the entire HCV RNA positive sample.

Conclusions: The findings of $6.2 \%$ prevalence of $\mathrm{HCV}$ infection based on HCV RNA test confirmed that there is Hepatitis C virus in Kaduna State with genotype $1 \mathrm{~b}$ as the predominant genotype found in all the three senatorial zones.

\section{INTRODUCTION}

Blood test were developed to identify hepatitis B in 1963 and hepatitis A in 1973, but many of the blood samples taken for post transfusion illness tested negative for hepatitis $A$ and Hepatitis $B$. The unidentified cases were classified as non A, non B hepatitis $(1,2)$. In the 1980's, investigators from the centre for disease and control and Chiron Corporation identified the virus to be Hepatitis C virus (2). In 1990, blood banks began screening blood donors for hepatitis C, and it was not until 1992 that a blood test was perfected that effectively eliminated HCV from the blood transfusion supply $(2,3)$. It is now believed that approximately 90 to $95 \%$ of cases previously classified as non A, non B hepatitis were actually hepatitis C (3). Hepatitis $C$ virus (HCV) is a member of the family Flaviviridae, placed in a new monotypic genus-Hepacivirus $(4,5)$. The viral genome is a singlestranded RNA molecule approximately $9.6 \mathrm{~kb}$ in length which is positive sense and possesses a unique open reading frame, coding for a single polyprotein, flanked by untranslated regions at both its $5^{\prime}$ and $3^{\prime}$ ends. The length of the polyprotein-encoding region varies according to the isolate and genotype of the virus from 3008 to 3037 amino acids (6). The genus Hepacivirus consists of 6 major genotypes further

divided into subtypes (7). HCV genotypes 1, 2 and 3 are the most commonly detected types worldwide (8). Genotype 1 in particular has been extensively reported by other authors in Brazil (9), Chile (10), Uruguay (11), Argentina (12) and Venezuela (13). HCV genotype 1a, $1 \mathrm{~b}$ originated about 100 years ago and are evolving at faster rate than genotypes 4 and 6 (8).

The genotypes can be distinguished by whole genome or genome fragment sequencing, genotype specific amplification of a genomic region or PCR amplification followed by hybridization or restriction digestion among other methods $(3,14)$. In the United States of America, the incidence of post transfusion $\mathrm{HCV}$ dropped from $3.84 \%$ to $0.57 \%$ after $\mathrm{HCV}$ screening was introduced in 1990. The incidence of 
transfusion-related $\mathrm{HCV}$ is however still higher in developing countries (15). Nigeria belongs to the group of countries highly endemic for viral hepatitis including $\mathrm{HCV}$. The prevalence of $\mathrm{HCV}$ among blood donors ranges from $6.0 \%$ to $9.5 \%(16,17,18)$. However, there is no knowledge of HCV RNA prevalence in Kaduna state.

\section{MATERIALS AND METHODS.}

Ethical approval was obtained from the ethical committee of the Ahmadu Bello University Teaching Hospital Shika-Zaria and from the Directors of General Hospital Kafanchan and Yusuf Dantsoho Hospital Tudun Wada Kaduna. Informed consent form written in English and Hausa was administered to each person whose blood was collected. Two hundred and fifty nine (259) blood samples were collected from 139 blood donors and 120 outpatient department attendees in three hospitals one in each of the three senatorial zones in Kaduna state using systematic sampling method. Blood samples $(5 \mathrm{ml})$ were collected into blood bottles containing anticoagulant. The plasma samples were separated into sterile bottles by centrifugation at $1000 \mathrm{rpm}$ for 30 minutes and the plasma samples were stored at $-20^{\circ} \mathrm{C}$ initially in the various hospitals and were later transported by cold box and stored at $-20^{\circ} \mathrm{C}$ in Virology laboratory at the Department of Microbiology, Ahmadu Bello University Zaria immediately until required for the analysis.

\section{HCV ANTIBODY DETECTION BY HCV ELISA (BIOTEC U.K)}

The plasma samples were initially tested for the presence of Hepatitis $C$ virus antibodies using a commercially available third generation HCV Enzymelinked immunosorbent assay (Biotech Laboratories, 1P53RG.UK.). The procedure according to the manufacturer was used. The plates were read according to manufacturer's instruction as follows: The wells were assessed visually immediately after the second incubation. Medium to dark blue colour indicated positive result.

No colour or very pale colour indicated negative result. The intensity of the reaction was photometrically quantitated with a dual filter Enzyme Immuno Assay Reader (Sigma diagnostics EIA Multiwell Reader 11) immediately using O.D at 450nm, $630 \mathrm{~nm}$.

\section{REVERSE TRANSCRIPTION POLYMERASE CHAIN REACTION (RT-PCR). \\ HCV RNA Extraction procedure.}

The lysis solution and washing solution were brought to $65^{\circ} \mathrm{C}$ and Lysis solution $(450 \mu \mathrm{l})$ and $100 \mu \mathrm{l}$ of samples were added to appropriate labelled tubes. All tubes were vortexed and centrifuged for $30 \mathrm{sec}$. Sorbent was vortexed vigorously and $25 \mu$ l were added to each tube and all tubes were vortexed for $7 \mathrm{sec}$ and were incubated at room temperature for 10 minutes.
The tubes were vortexed periodically during incubation. The tubes were centrifuged for $30 \mathrm{sec}$ at $10,000(\mathrm{rpm})$ and the supernatants were discarded without disturbing the pellet using fresh pipette tips. Washing solution $(400 \mu \mathrm{l})$ was added to each tube vortexed vigorously and were centrifuged for $30 \mathrm{sec}$ at $10,000 \mathrm{rpm}$. The supernatants were then carefully removed without disturbing the pellet using fresh pipette tips. Seventy percent ethanol $(500 \mu \mathrm{l})$ was added to each tube and was vortexed vigorously and was centrifuged for $30 \mathrm{sec}$ at $10,000 \mathrm{rpm}$. The supernatant was carefully removed and discarded from each tube without disturbing the pellet using fresh pipette tips. The procedure in this step was repeated. Acetone $(400 \mu \mathrm{l})$ was added to each tube and was vortexed vigorously and was centrifuged for 30 sec at $10,000 \mathrm{rpm}$. The supernatants were carefully removed without disturbing the pellet with fresh tips between tubes. All tubes were incubated with open cap for 10 minutes at $60^{\circ} \mathrm{C}$. The pellets were resuspended in $50 \mu \mathrm{l}$ of RNA-diluents and were incubated for 10 minutes at $60^{\circ} \mathrm{C}$ and were vortexed periodically during incubation. The tubes were centrifuged for 1 minute at maximum speed of $16,000 \mathrm{rpm}$. The supernatant which contain the RNA were carefully removed into sterile tubes ready for use.

\section{Reverse Transcription}

\section{Preparation of Reaction Mix for 12 Reactions}

RT-G-mix-1 $(5 \mu \mathrm{l})$ was added into tube containing RTMix, vortexed for $10 \mathrm{sec}$ and was briefly

centrifuged. M-MLV $(6 \mu \mathrm{l})$ was added into tube with reaction mixed, vortexed and centrifuged

for $7 \mathrm{sec}$. This was immediately used for reverse transcription.

\section{Reverse Transcription}

Reaction mix $(10 \mu \mathrm{l})$ was added to each tube. The tubes with extracted RNA were re-centrifuged for 2 minutes at $16,000 \mathrm{rpm}$. Supernatants containing extracted RNA $(10 \mu \mathrm{l})$ were taken to appropriate tubes. The tubes were placed into thermocycler(Techgene, model FTGENE $5 \mathrm{D}$, Serial NO 121254-4) and were incubated at $37^{\circ} \mathrm{C}$ for 30 minutes. Each cDNA sample obtained was diluted 1:2 with T E-buffer [20 $\mu$ l of T E buffer was added to each tube] and was ready for used.

Enzymes and oligonucleotide primers for the polymerase chain reaction.

Taq deoxyribonucleic acid (DNA) polymerase and moloney murine leukemia virus (M-MLV) reverse transcriptase were obtained from (Sacace Biotechonologies, Italy). Primers utilized were specific for region of $\mathrm{HCV}$ genome with the 338bp for genotype 1a, 395bp for genotype 1b, 286bp for genotype 2 , and $227 \mathrm{bp}$ for genotype $3 \mathrm{a}$. Primers oligonucleotide sequences include: 
5'-CAGTCACTGAGAGCGACATCCGTACG-3' (for

1a)

5'-AGGCCACTGCGGCCTGTCGAGCTGCGAA-3'

(for $\mathrm{lb}$ )

5'-TATGTTCAACAGCAAGGGCCAGA-3' (for 2).

5'-CTCGGACCCTGACTTTCT-3' (for 3a)

5'-CCTGGTCATAGCCTCCGTGAA-3' (antisense

primer for all genotypes).

Polymerase Chain Reaction using HCV genotype specific primers.

Tubes (12) of PCR Mix-1 genotypes $1 \mathrm{a} / 1 \mathrm{~b}$ tubes and 12 of PCR Mix-1 genotypes 2/3a including 1 tube for negative control and 1tube for positive control were prepared. PCR Mix-2 (10 $\mu \mathrm{l})$ was added to each tube. cDNA samples obtained after RT step $(5 \mu \mathrm{l})$ were added to appropriate tubes. DNA buffer $(5 \mu \mathrm{l})$ was added to negative control tube of amplification. cDNA 1a $(5 \mu \mathrm{l})$ was added to the PCR-Mix -1 genotype $1 \mathrm{a} / 1 \mathrm{~b}$ tube. cDNA $1 \mathrm{~b}(5 \mu \mathrm{l})$ were added to the PCR-Mix -1 genotype $1 \mathrm{a} / 1 \mathrm{~b}$ tube. cDNA $2(5 \mu \mathrm{l})$ were added to the PCR Mix-1 genotypes $2 / 3$ a tube. cDNA 3a $(5 \mu l)$ were added to the PCR Mix-1 genotypes 2/3a tube.

The tubes were closed and transferred to the thermocycler only when temperature reached $95^{\circ} \mathrm{C}$. The reactions were started after the thermocycler was programmed. Step 1 (Initial denaturation): $95^{\circ} \mathrm{C}, 5$ minute. Step 2 (42 cycles): Denaturation at $95^{\circ} \mathrm{C}, 1$ minute; annealing at $68^{\circ} \mathrm{C}, 1$ minute; extension at $72^{\circ} \mathrm{C}$, 1 minute. Step 3 final extension at $72^{\circ} \mathrm{C}, 1$ minute and finally $10^{\circ} \mathrm{C}$ for storage temperature.

\section{Detection of the PCR Products}

The amplified cDNAs were detected by electrophoresis.

Agarose concentration of $1.0 \%$ was melted by boiling in microwave oven for 2 minutes. The solubilized agarose was cooled down to $65^{\circ} \mathrm{C}$ and $5 \mu$ l ethidium bromide was added. Formoldehyde $(6.5 \mathrm{ml})$ was added to every $100 \mathrm{ml}$ of gel. The gel was poured into taped gel trays and well-formed combs were placed near the edge and middle of gel and were covered with plastic box to prevent evaporation and allowed to harden for 1 hour. Electrophoresis tanks were filled with $10 \mathrm{mM}$ sodium phosphate buffer. Gel was totally submerged in buffer at a level not more than $1 \mathrm{~cm}$ above the gel and the combs were removed. Samples were prepared by adding $5 \mu \mathrm{l}$ of gel loading buffer to each $15 \mu \mathrm{l}$ sample. Samples were loaded and 75volts was applied for 45 minutes.

The power supply was switch off when dye front has run approximately $80 \%$ of gel length and the gel trays containing the gel were removed. The gel were then soaked in $5 \mathrm{mM} \mathrm{NaoH}$ and blotted into nylon membrane. Gels were examined on UV transluminator using protective glass. Photographs were taken and the resulting photographs were used to determine the distance migrated for each band.

\section{Identification of Bands of PCR Products}

The control cDNA for genotypes 1a, 1b, 2, 3a and kilobase ladder (used as marker) were used for the identification of the bands as shown in figure 1 below. The length of specific amplified DNA fragments is: HCV genotype $1 a-338$ bp, HCV genotype $1 b-395$ bp, HCV genotype 2 - 286 bp, HCV genotype $3 a-227$ bp.

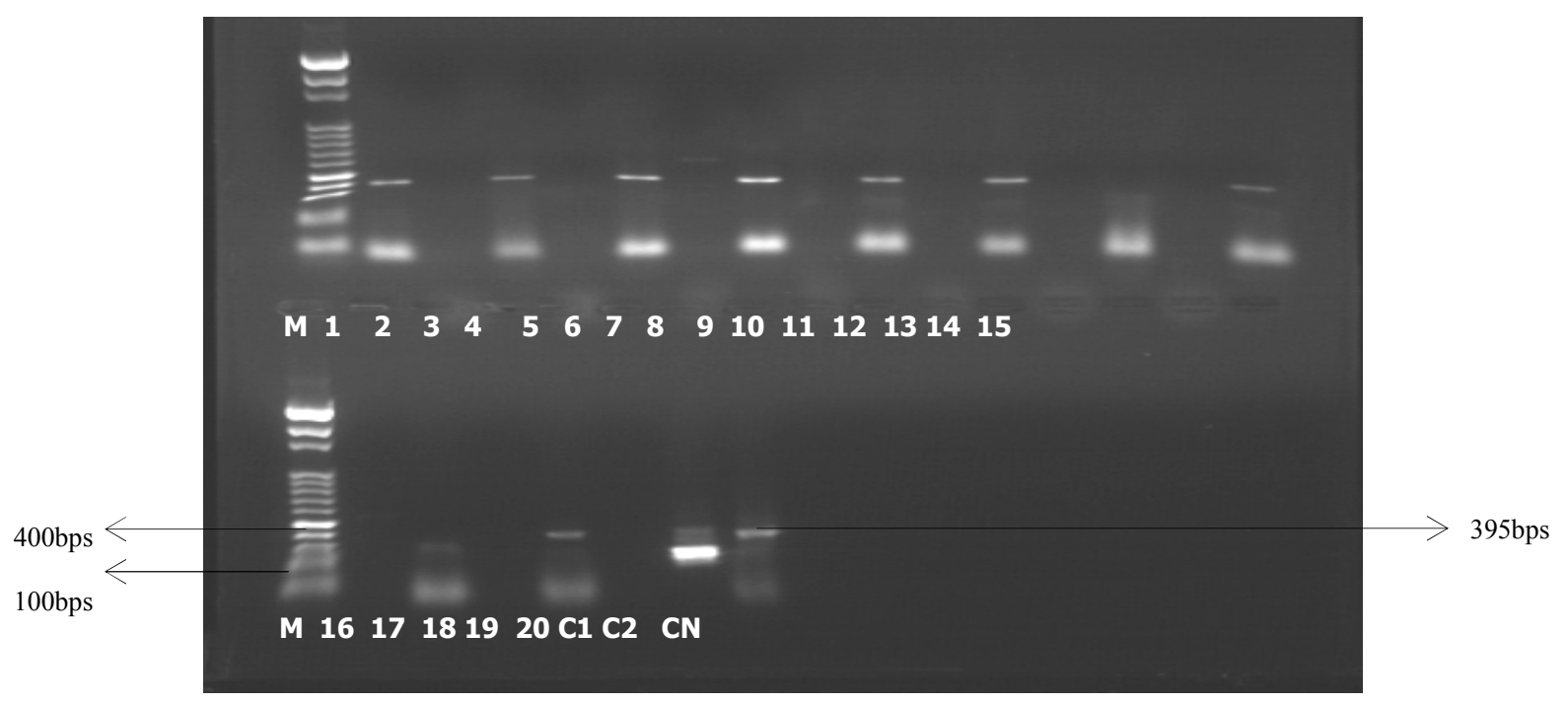

Fig. 1: Shows Agarose gel electrophoresis of HCV RNA using specific primers for genotype 1a, 1b, 2 and 3a. Analysis of the result is based on the presence or absence of specific bands of amplified DNA on agarose gel. Lane M, marker (1000bps); Lane 1, 3, 5, 7, $9,11,13,15,17 \& 19$, genotypes $1 \mathrm{a} / 1 \mathrm{~b}$; Lane $2,4,6,8,10,12,14,16,18 \& 20$, genotypes 2/3a; Lane C1, positive control for genotypes 2/3a; Lane C2, positive control for genotypes 1a/1b; Lane CN, negative control of amplification. 


\section{DATA ANALYSIS}

The data were analyzed at Data Processing Unit, Institute of Agriculture Research (IAR), ABU, Zaria using SPSS Software Version 13.0. Chi-square test was used at $95 \%$ confidence interval ( $\mathrm{P} \leq 0.05)$.

\section{RESULTS}

Out of the 259 plasma specimens screened for Hepatitis C virus in this study, 20(7.7\%) were positive for anti-HCV antibodies by ELISA and $16(6.2 \%)$ of the antibodies positive specimen were positive for $\mathrm{HCV}$
RNA (Table 1). The prevalence of HCV per age group has shown that 21-40 age group has the highest prevalence rate of $14(7.2 \%) \mathrm{HCV}$ RNA followed by $41-$ 60 age group with $2(5.6 \%) \mathrm{HCV}$ RNA, Also, the $\mathrm{P}$ value $(P=0.735)$ indicated that there is no significance association between age and HCV infection. Of the 139 blood donors tested, 8 (5.8\%) were HCV RNA positive. Similarly, 120 were tested from the outpatient Department Attendees and 8 (6.7\%) were HCV RNA positive (Table 2).

Table 1: Distribution of HCV among blood donors and Outpatient Department attendees in the Senatorial Zones

\begin{tabular}{cccc}
\hline Zone & Number Tested & Number (\%) Positive \\
& & HCV Ab & HCV RNA \\
\hline Southern & 46 & $4(8.6)$ & $4(8.6)$ \\
Central & 130 & $12(9.2)$ & $8(6.2)$ \\
Northern & 83 & $4(4.8)$ & $4(4.8)$ \\
\hline Total & 259 & $20(7.7)$ & $16(6.2)$ \\
\hline
\end{tabular}

Chi square value $=0.286 ; \mathrm{P}=0.087$ at $95 \%$ confidence interval $(\mathrm{P} \leq 0.05)$

Table 2: Age Distribution of HCV Positive Cases

\begin{tabular}{|c|c|c|c|c|c|c|}
\hline \multirow[b]{2}{*}{ Zone } & \multicolumn{2}{|c|}{ Blood Donors } & \multicolumn{2}{|c|}{ General Population } & \multicolumn{2}{|l|}{ Total } \\
\hline & $\begin{array}{l}\text { No. } \\
\text { Tested }\end{array}$ & $\begin{array}{l}\text { No. }(\%) \\
\text { HCV } \\
\text { POS }\end{array}$ & $\begin{array}{l}\text { No. } \\
\text { Tested }\end{array}$ & $\begin{array}{l}\text { No. }(\%) \\
\text { HCVPOS }\end{array}$ & $\begin{array}{l}\text { No. } \\
\text { Tested }\end{array}$ & $\begin{array}{l}\text { No. } \quad(\%) \\
\text { HCVPOS }\end{array}$ \\
\hline$\leq 20$ & 4 & $0(0)$ & 24 & $0(0)$ & 28 & $0(0)$ \\
\hline $21-40$ & 113 & $7(6.2)$ & 81 & $7(8.6)$ & 194 & $14(7.2)$ \\
\hline $41-60$ & 22 & $1(4.5)$ & 14 & $1(7.1)$ & 36 & $2(5.6)$ \\
\hline $61-80$ & 0 & $0(0)$ & 1 & $0(0)$ & 1 & $0(0)$ \\
\hline Total & 139 & $8(5.8)$ & 120 & $8(6.7)$ & 259 & $16(6.2)$ \\
\hline
\end{tabular}

Chi - Square Value $=2.006 ; \mathrm{P}=0.735$ at $95 \%$ Confidence Interval $\mathrm{P} \leq 0.05$

\section{DISCUSSION}

The prevalence rate of $7.7 \%$ anti-HCV antibodies found in this study indicated a high prevalence of the disease in Kaduna State. It is higher than the earlier report of $6.0 \% \mathrm{HCV}$ prevalence from Jos (16), and slightly lower than the $8.4 \% \mathrm{HCV}$ prevalence reported from Abuja (17). The RT-PCR finding of $6.2 \% \mathrm{HCV}$ prevalence is slightly higher than the world Health Organization report of $5.3 \% \mathrm{HCV}$ prevalence rate in
Africa (19). The prevalence of $5.8 \% \mathrm{HCV}$ infection among blood donors and $6.7 \% \mathrm{HCV}$ prevalence among outpatient Department attendees has however shown that the outpatient Department attendees had the highest prevalence among the study group. This confirms that outpatient Department attendees are patients seeking medical attention while blood donors were assumed to be healthy individuals. Hepatitis C 
virus genotypes were determined by RT-PCR with HCV specific primers for genotype $1 \mathrm{a}, 1 \mathrm{~b}, 2$ and $3 a$ and primers for all other genotypes were also used. Genetically, the HCV genotype $1 \mathrm{~b}$ was found to be the genotype in circulation in Kaduna State, while in Abuja, genotype $1 \mathrm{a}$ and $1 \mathrm{~b}$ had been reported (17). Genotype assignment helps in assessing disease prognosis and assist in establishing the appropriate dosage and duration of treatment $(3,20)$. Genotype assignment also helps in determining the type of vaccine to be used. Currently there is no HCV vaccine. The report of HCV genotype $1 \mathrm{~b}$ in Kaduna State offers valuable information for its consideration as a vaccine candidate when the search for $\mathrm{HCV}$ vaccine seriously on course becomes a reality.

\section{CONCLUSION}

The findings of $6.2 \%$ prevalence of $\mathrm{HCV}$ infection based on HCV RNA test confirmed that there is Hepatitis C virus in Kaduna State. Genotype $1 \mathrm{~b}$ was found in all the 16 positive HCV RNA samples. This

\section{REFERENCES.}

1. Sharara A I., Christine M H. and John D H. Hepatitis C. Ann. Int. Med.1996; 125: 658 -668 .

2. Alan, F. A Brief History of Hepatitis C. Hep. C S. Pr. 2006; 2: 1- 3.

3. Michael, L., Maria, E., Sam, P., David, H. and Carl, W. Hepatitis C Genotyping By Denaturing High Performance Liquid Chromatography. J. Clin. Microbiol. 2004; 42 (91): $158-163$.

4. Nahum, M., Daniel, M., Norbeto, C C., Jesus, B., Richardo C. and Misael, U. Prevalence of $\mathrm{HCV}$ Infection Among Hemodialysis Patients at a Tertiary Care Hospital in Mexico City, Mexico. J. Clin. Microbiol. 2004; 42(9): 4321 - 4322.

5. Liang, T J. Shortened Therapy for Hepatitis C Virus Genotype 2 or 3 - is Less More? N. Engl. J. Med. 2007; 357(92): 176 - 278.

6. Chamberlain, R W., Adams, N., Saeed, A A., Simmonds, P. \& Elliott, R.M. Complete nucleotide sequence of a type 4 hepatitis $C$ virus variant, the predominant genotype in the Middle East. J. Gen. Virol. 1997; 78: 1341-1347.

7. Jenny, M., Yoann, M. Sylvie, A. Andre, C., Chistelle, R., Frederic L., Andre, E., Serge, P., Philippe, G., Odile, B., Roger, C., Emmanuel, G., Paul, D. and Raymond, C. HCV Genotypes in Caribbean Land of suggests that genotype $1 \mathrm{~b}$ is the predominant genotype in Kaduna state.

\section{RECOMMENDATION}

Hepatitis $C$ virus should be taken seriously and should be included among the blood borne pathogen that are tested before blood transfusion in government and private hospitals in Kaduna state. The health system should be strength to support all HCV infected persons medically and socially, as well as supporting vaccine development research.

\section{ACKNOWLEDGEMENTS}

We thank professor A .A. Amad for his high contribution to this work. We appreciate the Director of Centre for Biotechnology Research, Professor A. J. Nok who allowed the used of the center. We thank the entire staff of Biotechnology centre who assisted in one way or the other. We thank the Kaduna State Ministry of Health for financial support.

Martinique. J. Clin. Microbiol. 2004; 42 (2): $784-791$.

8. Gismondi, M I., Estela, I T., Saul, G., Maria, C G. and Maria, V P. HCV Infection in Infants and Children from Argentina. J. Clin. Microbiol. 2004; 42 (3): 1199 - 1202.

9. Krug, L P., Lune, V R., Kuta, N I. HCV Genotype in Southern Brazil. Braz. J. Med. Res. 1996; 29: 1629 - 1633.

10. Munox G M., Velasco, V., Thiers, C. Prevalence and Genotype of HCV in Blood Donors and in Patients with Chronic Liver Disease and Hepatocellular Carcinoma in a Chilean population. Chil. J. med. 1998; 4(2):12-15.

11. Colina, R C., Azambuja, A. and Uriarte C. Evidence of Increasing Diversification of HCV. J. Gen. Virol. 1999; 80: 1377 - 1382.

12. Quarieric, J B., Roberton, B. and Mathet, M. Genomic and Phytogenetic Analysis of HCV Isolates from Argentine Patients: A Six Year Retros Pective Study. J. Clin. Microbiol. 2001; 38: 4560 - 4568.

13. Pujol, F H., Loureiro, M. and Devesca, L. Determination of genotypes of Hepatitis C Virus in Venezuela by Restriction Fragment Length polymorphism. J. Clin. Microbiol. 2002; 35: $1870-1872$. 
14. Solange, B. and Guilherme, O. Molecular Epidemiology of the HCV in Braz. Genet. Mol. Res. 2003; 2(1): 117 123.

15. Theodore, S Y. and Mazen, M J Epidemiology of Hepatitis C Virus (HCV) Infection. Int. J. Med. Sci. 2006; 3: $41-46$.

16. Egah, D Z., Mandong, B M., Gomwalk, N E.,Audu, E S.,Banwat, E B.and Onile,B A. Hepatitis C Virus Antibodies among Blood Donors in Jos, Nigeria. Ann. Afr. Med. 2004; 3 (1): 35 - 37.

17. Agwale, M S., Lorine T., Chad, W., Odama, L., Kimy, L., Dolores, D., Negedu, R M., Israel, A., Shehu, B. M., Uford, I. Granham, B. and Rainer, Z. Prevalence of Hepatitis C
Virus (HCV) Co - infected in HIV infected Individuals in Nigeria and Characterization of HCV Genotypes. J. Clin. Virol. 2004; F53 - F56.

18. Sheyin, Z., Ahmad, A A., Jatau, E D. Determination of HCV Antibodies Amongst Blood Donors in Kaduna Metropolis. Biol. Env. J. Trop. 2007; 4(1):54-57.

19. World Health Organization (WHO) (2000). Hepatitis C. http://www.who.int/mediacentre/fact sheets/fs164/en/

20. Alan, F. Effect of Hepatitis $C$ and its Treatment. Hep. C V. S.Pr. 2010; 13(1):111. 